\title{
Effect of Fly Ash on the Electrochemical Performance of 316L Stainless Steel Concrete Reinforcement in Saline Environments Attacked by Acid Rain
}

\author{
Sofia Tsouli ${ }^{1}$, Angeliki G. Lekatou ${ }^{1,2^{*}}$, Pantelis Goutzos $^{1}$, Spyridon Kleftakis ${ }^{1}$ \\ ${ }^{1}$ Laboratory of Applied Metallurgy, Department of Materials Science and Engineering, School of \\ Engineering, University of Ioannina, 45110, Ioannina, Greece \\ ${ }^{2}$ Institute of Materials Science and Computing, University Research Center of Ioannina (URCI), \\ 45110, Ioannina, Greece
}

\begin{abstract}
The present study investigates the effect of fly ash (FA) as a corrosion inhibitor on the electrochemical performance of 316L stainless steel concrete reinforcement in a simulating concrete pore solution exposed to a coastal environment that is severely polluted by acid rain (AR). The corrosion behavior of $316 \mathrm{~L}$ stainless steel is examined by means of cyclic (reverse) polarization in order to evaluate the susceptibility of 316L rebars to localized corrosion. A slightly alkaline solution simulating corroded concrete that has exposed the reinforcement directly to acid rain attack $(\mathrm{pH} \approx 8)$ was chosen as electrolyte. The solution contained $\mathrm{Ca}(\mathrm{OH})_{2}$ partially replaced by FA ( 0 wt. $\%$ - 25 wt.\%), an acid rain simulating solution and $3.5 \mathrm{wt} \% \mathrm{NaCl}$. The beneficial effect of FA partially replacing $\mathrm{Ca}(\mathrm{OH})_{2}$ (up to $20 \mathrm{wt} . \% \mathrm{FA}$ ) on the corrosion resistance of $316 \mathrm{~L}$ rebars was manifested by slower corrosion kinetics, nobler corrosion potentials and less susceptibility to localised corrosion. However, these trends were reversed at 25 wt.\% FA. The above performance was compared with the corrosion performance in the same electrolyte but without the addition of $3.5 \mathrm{wt} . \%$ $\mathrm{NaCl}$.
\end{abstract}

\section{Introduction}

Reinforced concrete has been the most widely employed structural material through the last 200 years due to its relatively low cost compared to other building materials, high compressive strength, durability and long service lifetime [1-4]. Therefore it is utilized for the construction of infrastructure exposed to different types of environment, from mild to extremely aggressive [1]. Steel reinforcement presents good corrosion performance due to the formation of a protective passive film on the surface of the steel as a consequence of the high alkaline environment of the concrete $(\mathrm{pH} \approx 12.5$ - 13.5) [2,3,5-7], which is attributed to the existence of $\mathrm{NaOH}, \mathrm{KOH}$ and $\mathrm{Ca}(\mathrm{OH})_{2}$ in its pore solution [5].

* Corresponding author: alekatou@uoi.gr 
Since durability of steel reinforcement in concrete structures under extreme environmental conditions and serviceability are key cornerstones for the service lifetime, structural performance and seismic resistance of reinforced concrete structures, they have been of great interest to the scientific and industrial community over the past decades $[1,7,8]$. Concrete infrastructure may undergo premature deterioration and failure due to corrosion of steel reinforcement in case it is exposed to either chloride containing environments $[1,2,6,7,9,10]$, carbonation [2,5-7] or chemical deterioration, e.g. acid attack $[3,4,8,11]$. Corrosion affects the bond strength between concrete and steel reinforcement, since the formation of corrosion products with increased volume compared to the original metal in the concrete pores leads to the formation of internal stresses, cracking and eventually spalling of concrete around the rebars $[1,3,11]$.

The remarkable acceleration of the degradation or reinforced concrete provoked by acid rain (AR), particularly in the vicinity of industrial and urban areas, has also a serious impact on the durability and seismic resistance of reinforced concrete structures $[3,4]$. The combined effect of $\mathrm{H}^{+}$and $\mathrm{SO}_{4}{ }^{2-}$ is mainly responsible for the deterioration of concrete under acid rain attack $[3,4]: \mathrm{H}^{+}$promotes the decomposition of hydration products, i.e. C-S-H (calciumsilicate-hydrate), $\mathrm{xCaO} \cdot \mathrm{Al}_{2} \mathrm{O}_{3} \cdot \mathrm{yH}_{2} \mathrm{O}\left(\mathrm{C}_{\mathrm{x}} \mathrm{AH}_{\mathrm{y}}\right.$ or C-A-H: calcium-aluminate-hydrate $)$ and ettringite $\left(3 \mathrm{CaO} \cdot \mathrm{Al}_{2} \mathrm{O}_{3} \cdot 3 \mathrm{CaSO}_{4} \cdot 32 \mathrm{H}_{2} \mathrm{O}\right)$, leading to the collapsible corrosion of microstructures, while $\mathrm{SO}_{4}{ }^{2-}$ reacts with the cement hydration products to form sulphate hydrates, thereby inducing the expansive corrosion of microstructures [3]. Ghafoori et al. reported that the concrete deterioration due to sulphate attack includes at first the formation of ettringite (Equation (1)), secondly the formation of monosulphoaluminate (Equation (2)) and finally the formation of ettringite once more (Equation (3)), leading to significant internal pressure and, eventually, cracking and spalling of concrete [11].

$$
\begin{gathered}
3 \mathrm{CaO} \cdot \mathrm{Al}_{2} \mathrm{O}_{3}+3\left(\mathrm{CaSO}_{4} \cdot 2 \mathrm{H}_{2} \mathrm{O}\right)+26 \mathrm{H}_{2} \mathrm{O} \rightarrow 3 \mathrm{CaO} \cdot \mathrm{Al}_{2} \mathrm{O}_{3} \cdot 3 \mathrm{CaSO}_{4} \cdot 32 \mathrm{H}_{2} \mathrm{O} \\
2\left(3 \mathrm{CaO} \cdot \mathrm{Al}_{2} \mathrm{O}_{3}\right)+3 \mathrm{CaO} \cdot \mathrm{Al}_{2} \mathrm{O}_{3} \cdot 3 \mathrm{CaSO}_{4} \cdot 32 \mathrm{H}_{2} \mathrm{O}+4 \mathrm{H}_{2} \mathrm{O} \rightarrow 3\left(4 \mathrm{CaO} \cdot \mathrm{Al}_{2} \mathrm{O}_{3} \cdot \mathrm{SO}_{3} \cdot 12 \mathrm{H}_{2} \mathrm{O}\right) \\
\left.4 \mathrm{CaO} \cdot \mathrm{Al}_{2} \mathrm{O}_{3} \cdot \mathrm{SO}_{3} \cdot 12 \mathrm{H}_{2} \mathrm{O}+2\left(\mathrm{CaSO}_{4} \cdot 2 \mathrm{H}_{2} \mathrm{O}\right)+16 \mathrm{H}_{2} \mathrm{O} \rightarrow 3 \mathrm{CaO} \cdot \mathrm{Al}_{2} \mathrm{O}_{3} \cdot 3 \mathrm{CaSO}_{4} \cdot 32 \mathrm{H}_{2} \mathrm{O}\right)
\end{gathered}
$$

Nowadays, a wide variety of methods, such as corrosion inhibitors, reinforcement galvanization, cathodic protection, epoxy coatings on reinforcement etc., have been proposed in order to prevent or delay the corrosion of steel reinforcement [1,2,7,9-11]. Amongst them, the utilization of stainless steel reinforcement in concrete infrastructure is one of the most reliable solutions, especially in the case of highly aggressive environments, such as marine and saline environments, urban and industrial areas etc. $[2,6,7,10]$. Austenitic stainless steel reinforcement combines high corrosion resistance with good mechanical properties $[2,10,12,13]$. The corrosion resistance is attributed to the formation of a chromia-based passive film on the surface of the steel [2,7,12], as well as the beneficial presence of Mo (if present) and $\mathrm{Ni}$ that improve the stability of the passive film [12]. However, even $316 \mathrm{~L}$ stainless steel (that contains Mo and is low in C) is susceptible to localized corrosion after long-term exposure to severe environmental conditions, especially in the presence of $\mathrm{Cl}^{-}$ $[6,13]$.

The need for more structural materials with low cost and environmental impact, which, however, satisfy all the necessary mechanical requirements and present a long-term, good resistance to aggressive environmental conditions, has enhanced the utilization of industrial byproducts, such as fly ash (FA) $[1,9,11]$. FA, the main by-product of the combustion of pulverized coal in thermoelectric power stations, has been proven to enhance the durability of reinforced concrete by increasing chloride binding through the formation of Friedel's salt, the decrease in the chloride permeability and the refinement of the distribution of pore size and shape of concrete structure [1,9]. The corrosion resistance to various aggressive environmental agents $\left(\mathrm{Cl}^{-}, \mathrm{CO}_{2}\right.$, chemical attack) of concrete has also been found to be 
benefited by the addition of FA to the concrete. This is mainly attributed to the pozzolanic reaction of FA with the $\mathrm{Ca}(\mathrm{OH})_{2}$ from the hydration of cement (Equation (4)), which leads to the formation of insoluble hydration products $(\mathrm{C}-\mathrm{S}-\mathrm{H})$ with high resistance to acidic attack $[1,9,11]$. As Ghafoori et al. revealed, the resistance of concrete to sulfate attack, a major constituent of AR, is improved by the partial replacement of Ordinary Portland cement (OPC) with FA, since the additionally formed C-S-H and ettringite act as fillers of the spaces between concrete pores, consequently minimizing further sulfate penetration into the concrete [11].

$$
\mathrm{Ca}(\mathrm{OH})_{2}+\mathrm{H}_{4} \mathrm{SiO}_{4} \rightarrow \mathrm{Ca}^{2+}+\mathrm{H}_{2} \mathrm{SiO}_{4}{ }^{2-}+2 \mathrm{H}_{2} \mathrm{O} \rightarrow \mathrm{CaH}_{2} \mathrm{SiO}_{4} \cdot 2 \mathrm{H}_{2} \mathrm{O}
$$

Previous studies by the authors have manifested the beneficial effect of FA on the corrosion performance of $316 \mathrm{~L}$ in concrete pore solutions containing AR mimicking solutions [14-17]. An optimum content of FA addition (20 wt.\%) was identified. The present work aims at evaluating the effect of FA on the electrochemical degradation of $316 \mathrm{~L}$ stainless steel reinforcement in a slightly alkaline solution containing $\mathrm{NaCl}$. The above electrolyte simulates concrete attacked by both AR and saline action. Several studies have been devoted to the electrochemical performance of $316 \mathrm{~L}$ stainless steel as a concrete reinforcement under aggressive environmental conditions. In their vast majority, they concern the effect of seawater [6,7,18]. A limited number addresses the effect of acidic environments [14-17]. However, non-information can be found on the effect of coastal environments burdened by industrial and/or urban pollution, especially as far as restoration works of ancient monument and historical buildings are concerned.

\section{Experimental procedure}

\subsection{Materials}

316L austenitic stainless steel rebars (nominal wt.\% composition: $\mathrm{Fe}, 0.022 \% \mathrm{C}, 17.31 \% \mathrm{Cr}$, $10.08 \% \mathrm{Ni}, 2.02 \% \mathrm{Mo}, 0.54 \% \mathrm{Si}, 1.75 \% \mathrm{Mn}, 0.0032 \% \mathrm{P}, 0.0001 \% \mathrm{~S}$ ) of $6 \mathrm{~mm}$ diameter and $2.5 \mathrm{~cm}$ length were employed for the electrochemical testing. An alkaline pulverized fly ash (FA) from the Hellenic Public Power Corporation lignite mines in the Region of Western Macedonia, Greece was employed as a corrosion inhibitor. It mainly consisted of (in decreasing order of concentration) $\mathrm{CaO}, \mathrm{SiO}_{2}, \mathrm{Al}_{2} \mathrm{O}_{3}, \mathrm{SO}_{3}, \mathrm{Fe}_{2} \mathrm{O}_{3}$ (major amounts) and $\mathrm{MgO}$ (minor amount) [14].

\subsection{Electrochemical testing}

Cyclic potentiodynamic polarization testing was conducted on $316 \mathrm{~L}$ rebar segments according to ASTM G61-86 (3-4 replicates for each specimen), cut with a diamond saw. Their cutting edges were mounted in epoxy resin and further masked in PTFE, leaving a surface area of $\sim 2 \mathrm{~cm}^{2}$ to be exposed to the electrolyte. A standard three-electrode cell $(\mathrm{Ag} / \mathrm{AgCl} / 3.5 \mathrm{M} \mathrm{KCl}$ : reference electrode, $\mathrm{Pt}$ : counter electrode) was employed (Gill AC potensiostat / galvanostat by ACM Instr., $2 \mathrm{~h}$ immersion under open circuit to reach steady state, $10 \mathrm{mV} / \mathrm{min}$ scan rate, $25^{\circ} \mathrm{C}$ ). Reverse polarization was adopted in order to assess the susceptibility of the $316 \mathrm{~L}$ rebars to localized corrosion. According to the main concept of this technique, reverse current densities greater than the forward ones at the same anodic potential (forming the so called negative hysteresis loop) indicate susceptibility to localised corrosion $[19,20]$. The corrosion current densities were determined by Tafel extrapolation using linear regression analysis [19]. 
The electrolyte contained $1.8 \mathrm{~g} / \mathrm{l}$ of a mixture of $\mathrm{Ca}(\mathrm{OH})_{2}$ and $\mathrm{FA}$ at contents $0-25 \mathrm{wt} . \%$ of the dry mixture, an $\mathrm{AR}$ simulating solution and $3.5 \mathrm{wt} . \%$. NaCl. The acid rain mimicking solution had $\mathrm{a} \mathrm{pH}$ of 3.1 and contained $\left(\mathrm{g} / \mathrm{l} \mathrm{H}_{2} \mathrm{O}\right): \mathrm{H}_{2} \mathrm{SO}_{4}: 0.032, \mathrm{HNO}_{3}: 0.015$, $\left(\mathrm{NH}_{4}\right)_{2} \mathrm{SO}_{4}: 0.046, \mathrm{Na}_{2} \mathrm{SO}_{4}: 0.032, \mathrm{NaNO}_{3}: 0.021$ and $\mathrm{NaCl}: 0.084$ [21,22]. The initial $\mathrm{pH}$ of the electrolyte was 7.5 - 7.9 irrespectively of the FA content and was attained by the addition of extra $\mathrm{H}_{2} \mathrm{SO}_{4}$ to the electrolyte respectively to the FA content. Considering that an aqueous alkaline solution of saturated $\mathrm{Ca}(\mathrm{OH})_{2}\left(1.8 \mathrm{~g} / 1\right.$ of $\left.\mathrm{H}_{2} \mathrm{O}\right)$ with $\mathrm{pH} \approx 12.6$ simulates a concrete pore solution, i.e. the liquid located in the saturated pores and capillary voids of concrete $[2,7]$, this slightly alkaline electrolyte is postulated to simulate corroded concrete that has directly exposed the steel reinforcement to acid attack [8]. Simultaneously, as $3.5 \mathrm{wt} . \% \mathrm{NaCl}$ simulates marine environments [2,7], the electrolyte in the present work simulates concrete pore solution exposed to a coastal environment that is polluted by AR .

After the necessary metallographic preparation (cross-sectioning at ribs by a diamond saw and polishing by standard metallographic procedure), the microstructure of the $316 \mathrm{~L}$ rebars was inspected by Scanning Electron Microscopy (SEM) / Energy Dispersion X-ray spectroscopy (EDX) at the JeoL JSM 6510 LV /Oxford Instruments X-Act EDX system.

\section{Results and discussion}

\subsection{Cyclic potentiodynamic polarization}

Representative cyclic potentiodynamic polarization curves of 316L rebars during immersion in the slightly alkaline electrolyte $(\mathrm{pH} \approx 8)$ are illustrated in Fig. 1. Critical electrochemical values extracted from the polarization curves are listed in Table 1.

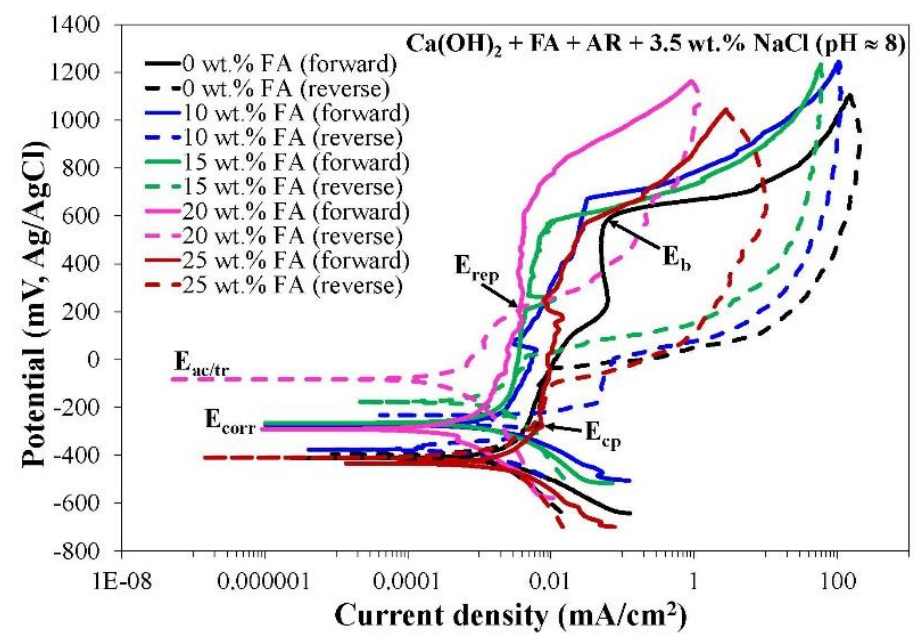

Fig. 1. Cyclic potentiodynamic behaviour of $316 \mathrm{~L}$ rebars in a slightly alkaline electrolyte containing $\mathrm{Ca}(\mathrm{OH})_{2}$ partially replaced by FA (0 - $\left.25 \mathrm{wt} . \%\right)$, an AR simulating solution and $3.5 \mathrm{wt} . \% \mathrm{NaCl}$.

All forward anodic scans reveal passive regions of high potential range (about 700 $900 \mathrm{mV}$ ) and quite low current densities $\left(\mathrm{i}<0.1 \mathrm{~mA} / \mathrm{cm}^{2}\right)$, indicating true passivity. However, reverse polarization has led to negative hysteresis, i.e. greater current densities at reverse polarization compared to the forward polarization for the same anodic potential for all FA contents indicating that $316 \mathrm{~L}$ has been subjected to localized corrosion. Nevertheless, negative hysteresis turns to positive at $\mathrm{E}_{\text {rep }} \geq \mathrm{E}_{\text {corr }}$ indicating a satisfactory resistance to localized corrosion. This evidence is also enchanced by the notably nobler or slightly nobler anodic-to-cathodic transition potential $\left(\mathrm{E}_{\mathrm{a} / \mathrm{c}}\right.$ tr $)$ values compared to the respective corrosion 
potential $\left(\mathrm{E}_{\mathrm{corr}}\right)$ values shown in all curves, i.e. nobler surfaces at $\mathrm{E}_{\mathrm{a} / \mathrm{c}}$ tr (reverse polarization) compared to those at $\mathrm{E}_{\text {corr }}$ (forward polarization). Moreover, the passive current densities $\left(\mathrm{i}_{\mathrm{p}}\right.$ ) decrease as FA increases from 0 to $20 \mathrm{wt} \%$, suggesting a corresponding decreasing conductivity. On the other hand, the " $25 \mathrm{wt} . \%$ FA" curve manifested the highest $i_{p}$ among the "FA" forward anodic curves, indicating the formation of the most conductive passive film.

Table 1. Electrochemical values of $316 \mathrm{~L}$ rebars immersed in the slightly alkaline electrolyte $(\mathrm{pH} \approx 8)$ containing $\mathrm{Ca}(\mathrm{OH})_{2}$ partially replaced by $0-25 \mathrm{wt} . \% \mathrm{FA}$, an AR simulating solution and $3.5 \mathrm{wt} . \%$ $\mathrm{NaCl}$. The values are drawn from the curves of Fig. 1. Ecorr: corrosion potential, icorr: corrosion current density, $\mathrm{i}_{\mathrm{p}}$ : passive current density ( middle of passive region)

\begin{tabular}{|c|c|c|c|}
\hline $\begin{array}{c}\text { Fly ash } \\
(\mathbf{w t .} \%)\end{array}$ & $\begin{array}{c}\mathbf{E}_{\text {corr }} \\
(\mathbf{m V}, \mathbf{A g} / \mathbf{A g C l})\end{array}$ & $\begin{array}{c}\mathbf{i}_{\text {corr }} \\
\left(\mathbf{m A} / \mathbf{c m}^{2}\right)\end{array}$ & $\begin{array}{c}\mathbf{i}_{\mathbf{p}} \\
\left(\mathbf{m A} / \mathbf{c m}^{2}\right)\end{array}$ \\
\hline 0 & -411 & 0.0025 & 0.050 \\
\hline 10 & -273 & 0.0025 & 0.009 \\
\hline 15 & -265 & 0.0021 & 0.005 \\
\hline 20 & -291 & 0.0005 & 0.004 \\
\hline 25 & -434 & 0.0028 & 0.010 \\
\hline
\end{tabular}

An increase in the corrosion resistance is manifested as the FA content increases up to 20 wt.\% FA, implied by: a) the reduction of the corrosion current density ( $\left.i_{\text {corr }}\right)$; b) the shift of the anodic polarization curves to lower current density values, c) the reduction of the passive current density values. The $\mathrm{E}_{\text {corr }}$ values of the "10-20 wt.\% FA" curves are nobler than those of the " 0 wt.\% FA curve, evidence of a higher pozzolanic activity [9]. The superiority of the " $20 \mathrm{wt} . \%$ FA" curve is evident in both Fig. 1 and Table 1 as it presents the lowest $i_{\text {corr }}$ and $i_{p}$ values, as well as the smallest surface area of the negative hysteresis loop. However, the trend of corrosion resistance increasing with FA content is reversed at the 25 wt.\% FA content, as the respective curve presents higher $i_{\text {corr }}$ and $i_{p}$ values and less noble $\mathrm{E}_{\text {corr }}$ compared to the "10-20 wt.\% FA" curves. Nevertheless, even in this case, the very low current densities values in the passive regime in combination with the slightly nobler $\mathrm{E}_{\mathrm{a} / \mathrm{c} \text { tr }}$ values compared to the respective $\mathrm{E}_{\text {corr }}$ values indicate a good corrosion resistance. The above trends are compatible with previous efforts on 316L $[14,16]$ and $304 \mathrm{~L}[15,17]$ immersed in various AR mimicking electrolytes containing $\mathrm{Ca}(\mathrm{OH})_{2}$ and $\mathrm{FA}$, whilst poor in $\mathrm{Cl}^{-}$. The beneficial effect of the FA partially replacing $\mathrm{Ca}(\mathrm{OH})_{2}$ on the corrosion resistance of the $316 \mathrm{~L}$ rebars is attributed to the increase in the pozzolanic and cementitious activities. Regarding the former activities, although the FA used in this study is $\mathrm{CaO}$-rich, it still contains reactive silica and alumina that react with $\mathrm{Ca}(\mathrm{OH})_{2}$ to form compounds (e.g. C-S-H, C-A-H) that are more resistant than $\mathrm{Ca}(\mathrm{OH})_{2}$ to the aggressive ions of AR. Regarding the latter activities, the FA of this study contains minerals, such as tricalcium aluminate $\left(\mathrm{C}_{3} \mathrm{~A}\right)$, dicalcium silicate $\left(\mathrm{C}_{2} \mathrm{~S}\right)$ and reactive calcium-aluminosilicate glass, that react with $\mathrm{CaSO}_{4}$ and $\mathrm{Ca}(\mathrm{OH})_{2}$ to form calcium silicate hydrate, monosulfoaluminate and calcium aluminate hydrate that can decrease the diffusivity of aggressive species [23,24].

Comparison of the voltammograms of $316 \mathrm{~L}$ in the $\mathrm{NaCl}-\mathrm{rich}\left(\mathrm{AR}+\mathrm{Ca}(\mathrm{OH})_{2}\right)$ electrolyte and the same electrolyte but $\mathrm{NaCl}$-poor [16] in Fig. 2, manifests that the relative electrochemical trends of both electrolytes, as far as the FA content is concerned, are similar. In more details, increasing FA contents up to $20 \mathrm{wt} . \%$ in the $\mathrm{NaCl}$-poor electrolyte has led to a shift of the forward anodic scans to lower current density values, and lower $i_{\text {corr }}$ values [16], indicating slower corrosion kinetics, as well as to nobler corrosion potential values $\left(\mathrm{E}_{\text {corr }}\right)$. This trend is also reversed at $25 \mathrm{wt} . \% \mathrm{FA}$. The $316 \mathrm{~L}$ rebars in the $\mathrm{NaCl}$-poor electrolyte 
present superior corrosion performance as compared to the NaCl-rich electrolyte in terms of more stable passive films (lower $\mathrm{i}_{\mathrm{p}}$ ), less thermodynamic tendency for corrosion (nobler $\mathrm{E}_{\text {corr }}$ in most cases), lower $i_{\text {corr }}[16]$ and higher breakdown potentials $\left(\mathrm{E}_{\mathrm{b}}\right)$. Most important, the markedly higher $E_{b}$ values (accompanied by positive hystereresis loops [16]) signify a higher resistance to localized corrosion, attributed to the notably lower presence of $\mathrm{NaCl}$ in the electrolyte. In fact, in the case of exposure to $\mathrm{AR}$ (poor in $\mathrm{NaCl}$ ), the markedly high $\mathrm{E}_{\mathrm{b}}$ values are ascribed to the transpassive dissolution of $\mathrm{Cr}_{2} \mathrm{O}_{3}$ and evolution of $\mathrm{O}_{2}$ [25].

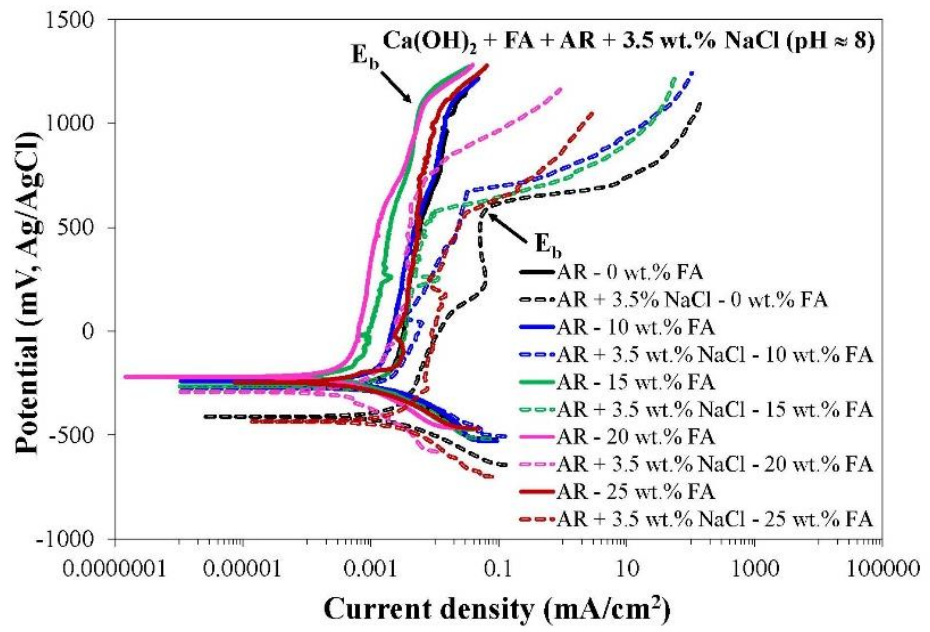

Fig. 2. Comparison of the polarization performance of $316 \mathrm{~L}$ rebars in two slightly alkaline electrolytes $(\mathrm{pH} \approx 8)$ containing $\mathrm{Ca}(\mathrm{OH})_{2}$, an $\mathrm{AR}$ simulating solution and $\mathrm{FA}$ at different contents $\left(0-25\right.$ wt. $\%$ of $\left.\left(\mathrm{Ca}(\mathrm{OH})_{2}+\mathrm{FA}\right)\right)$ (forward scans) with and without the addition of $3.5 \mathrm{wt} . \% \mathrm{NaCl}$.

\subsection{Microstructure of corroded specimens}

Figures 3a,b illustrate cross-sectional micrographs of $316 \mathrm{~L}$ rebars after cyclic potentiodynamic polarization in the slightly alkaline electrolyte at relatively low magnifications (20 wt.\% FA and $25 \mathrm{wt} . \%$ FA, respectively). A fine surface state in both cases is demonstrated.
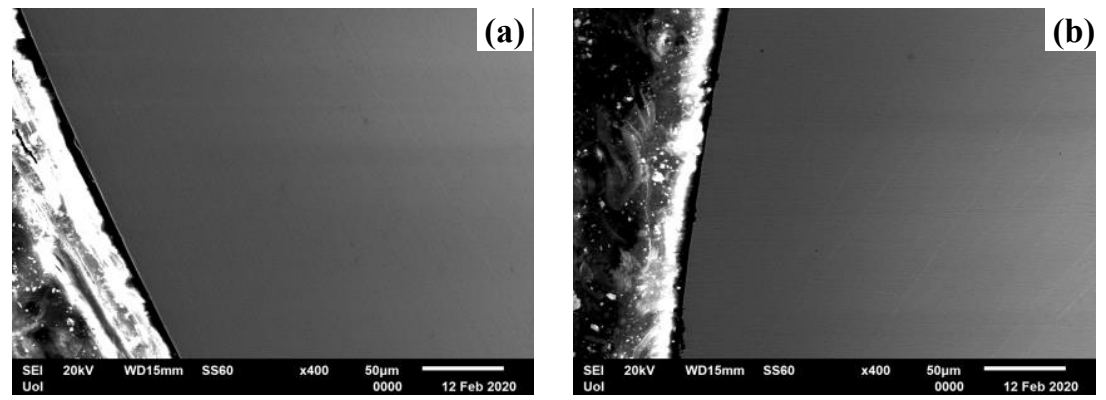

Fig. 3. SEM cross-sectional micrographs of $316 \mathrm{~L}$ rebars after cyclic potentiodynamic polarization in the slightly alkaline electrolyte containing $\mathrm{Ca}(\mathrm{OH})_{2}$, an $\mathrm{AR}$ simulating solution, $3.5 \mathrm{wt} . \% \mathrm{NaCl}$ and partial replacements of $\mathrm{Ca}(\mathrm{OH})_{2}$ with (a) $20 \mathrm{wt} . \% \mathrm{FA}$ and (b) $25 \mathrm{wt} . \% \mathrm{FA}$.

High magnifications are shown in Figure $4 \mathrm{a}, \mathrm{b}$. The increased presence of $\mathrm{Ca}, \mathrm{Si}$ and $\mathrm{Al}$ on the surface of the $316 \mathrm{~L}$ steel reinforcement manifests the positive effect of the 20 wt.\% FA content by the formation of a uniform compact Ca-based film (Fig. 4a). This 
film is probably the product of the pozzolanic and cementitious reaction between $\mathrm{Ca}(\mathrm{OH})_{2}$, $\mathrm{AR}$ and FA, as the increased presence of $\mathrm{Al}$ (more clearly) and Si (less clearly) show. This has also been shown in previous works on $316 \mathrm{~L}$ polarized in simulating concrete pores solutions containing AR and FA whilst poor in $\mathrm{Cl}^{-}[14,16]$. On the other hand, Figure 4b reveals the formation of pits on the $316 \mathrm{~L}$ rebars immersed in the electrolyte containing $\mathrm{Ca}(\mathrm{OH})_{2}$ replaced by $25 \mathrm{wt} . \% \mathrm{FA}$. It has previously been proven that high amounts of FA may form agglomerates with a relatively poor pozzolanic activity with $\mathrm{Ca}(\mathrm{OH})_{2}$ due to their low specific surface area. The agglomerates form thick deposits on the steel surface causing generation of differential aeration cells below them. Consequently, pits are formed that are filled with corrosion products from the interaction between $\mathrm{Ca}(\mathrm{OH})_{2}, \mathrm{FA}, \mathrm{AR}, \mathrm{Cl}^{-}$and steel [15-17].
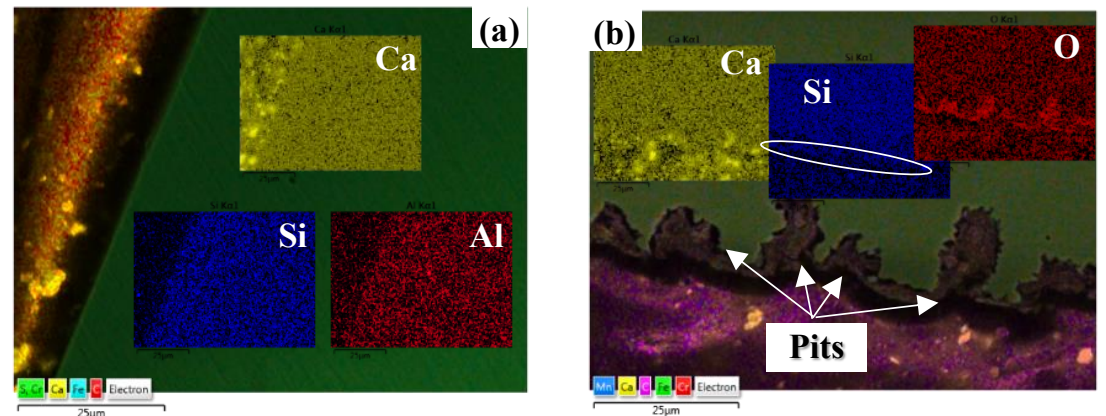

Fig. 4. SEM cross-sectional micrographs of 316L rebars after cyclic polarization in the slightly alkaline electrolyte containing $\mathrm{Ca}(\mathrm{OH})_{2}$, an AR simulating solution, 3.5 wt.\% $\mathrm{NaCl}$ and (a) 20 wt.\% FA and (b) 25 wt.\% FA (wt.\% of the mixture of $\mathrm{Ca}(\mathrm{OH})_{2}$ and FA); inset EDX elemental mapping. The ellipse in Fig. $4 \mathrm{~b}$ shows deposition of $\mathrm{Si}$ on the surface of the pits.

\section{Conclusions}

- Cyclic potentiodynamic polarization of $316 \mathrm{~L}$ stainless steel rebars in a slightly alkaline $(\mathrm{pH}=7.5-7.9)$ electrolyte containing $\mathrm{Ca}(\mathrm{OH})_{2}$ partially replaced with fly ash (FA) by $0-25 \mathrm{wt} . \%$, an acid rain (AR) simulating solution and $3.5 \mathrm{wt} . \% \mathrm{NaCl}$ has revealed very low corrosion current densities ( $\mathrm{i}_{\text {corr }}$ ), true passivity but susceptibility to localized corrosion (at high anodic potentials though).

- Removal of $3.5 \mathrm{wt} . \% \mathrm{NaCl}$ from the above solution led to slower corrosion of $316 \mathrm{~L}$ rebars, more stable passive films, less thermodynamic tendency for corrosion and absence of localized corrosion.

- Both electrolytes presented similar trends as regards the effect of the FA content, i.e. increase in the corrosion resistance with FA increasing in terms of lower corrosion current density, lower passive currents and nobler corrosion potential values. The above trends reversed at $25 \mathrm{wt} . \% \mathrm{FA}$.

- Microstructural examination of the $316 \mathrm{~L}$ rebars after cyclic potentiodynamic polarization in the slightly alkaline electrolyte (acid rain $+\mathrm{NaCl}$ ) revealed the beneficial effect of the $\mathrm{Ca}(\mathrm{OH})_{2}$ partial replacement with FA as regards the formation of uniform compact films consisting of products of the chemical interaction between $\mathrm{Ca}(\mathrm{OH})_{2}$ and FA. Nevertheless, high FA amounts $(25$ wt.\% FA content) promoted localized corrosion.

\section{References}

1. X. Shi, N. Xie, K. Fortune, J. Gong, Constr. Build. Mater. 30, 125-138 (2012) 
2. H. Luo, X. Wang, C. Dong, K. Xiao, X. Li, Corros. Sci. 124, 178-192 (2017)

3. M. Chen, K. Wang, L. Xie, Eng. Fail. Anal. 27, 272-285 (2013)

4. M. Mahdikhani, O. Bamshad, M. Fallah Shirvani, Constr. Build. Mater. 167, 929-935 (2018)

5. S. Hussain, D. Bhunia, S.B. Singh, J. Build. Eng. 10, 26-31 (2017)

6. W. Miao, Z. Gao, W. Hu, Int. J. Electrochem. Sci. 13, 771-784 (2018)

7. H. Luo, H. Su, C. Dong, X. Li, Appl. Surf. Sci. 400, 38-48 (2017)

8. Y. Fan, H. Luan, Constr. Build. Mater. 49, 407-416 (2013)

9. N. Chousidis, I. Ioannou, E. Rakanta, C. Koutsodontis, G. Batis, Constr. Build. Mater. 126, 86-97 (2016)

10. R.D. Moser, P.M. Singh, L.F. Kahn, K.E. Kurtis, Corros. Sci. 57, 241-253 (2012)

11. N. Ghafoori, M. Najimi, H. Diawara, M.S. Islam, Constr. Build. Mater. 78, 85-91 (2015)

12. C.M. Abreu, M.J. Cristóbal, R. Losada, X.R. Nóvoa, G. Pena, M.C. Pérez, Electrochim. Acta 49, 3049-3056 (2004)

13. P. Dhaiveegan, N. Elangovan, T. Nishimura, N. Rajendran, RSC Adv. 6, 47314-47324 (2016)

14. S. Tsouli, A.G. Lekatou, S. Kleftakis, The effect of fly ash on the corrosion performance of AISI 316 L stainless steel reinforced concrete for application to restoration works of ancient monuments, in $10^{\text {th }}$ International Symposium on the Conservation of Monuments in the Mediterranean Basin, Natural and Anthropogenic Hazards and Sustainable reservation, M. Koui, F. Zezza, D. Kouis (eds.), Springer International Publishing, Cham, Switzerland (2018), chapter 17, p. 171-178

15. S. Tsouli, A.G. Lekatou, S. Kleftakis, T.E. Matikas, P.T. Dalla, Procedia Struct. Integr. 10, 41-48 (2018)

16. S. Tsouli, A.G. Lekatou, C. Nikolaidis, S. Kleftakis, Procedia Struct. Integr. 17, 268-275 (2019)

17. A.G. Lekatou, S. Tsouli, C. Nikolaidis, S. Kleftakis, I.K. Tragazikis, T.E. Matikas, Frat. ed Integrita Strutt. 50, 423-437 (2019)

18. S. Tsouli, A.G. Lekatou, E. Siozos, S. Kleftakis, MATEC Web Conf. 188(03003), 1-8 (2018)

19. A.G. Lekatou, A.K. Sfikas, C. Petsa, A.E. Karantzalis, Met. 6(3), 1-23 (2016)

20. D.C. Silverman, Tutorial on cyclic potentiodynamic polarization technique, in Proceedings of the CORROSION 98 Research Topical Symposium, USA (1998)

21. G. Brunoro, A. Frignani, A. Colledan, C. Chiavari, Corros. Sci. 45, 2219-2231 (2003)

22. Kh.A. Ragab, R. Abdel-Karim, S. Farag, S.M. El-Ragh, H.A. Ahmed, H.A., Tribol. Int. 43, 594-601 (2010)

23. P.J. Tikalsky, R.L. Carrasquillo, The effect of fly ash on the sulfate resistance of concrete, Center for Transportation Research, University of Texas at Austin, Austin (1989)

24. V.G. Papadakis, Cem. Concr. Res. 30, 1647-1654 (2000)

25. M. Pourbaix, Atlas of electrochemical equilibria in aqueous solutions, NACE International, Cebelcor (1974) 